\title{
Perception of Primary Cervical Cancer Prevention in Adolescents in West Java
}

\author{
Nessa Sontiva ${ }^{1}$, Laili Rahayuwati ${ }^{2 *}$, Mamat Lukman ${ }^{3}$, Kusman Ibrahim $^{4}$, and \\ Ikeu Nurhidayah 5 \\ 1Faculty of Nursing, Universitas Padjadjaran; nsontiva@gmail.com \\ 2Department of Community Nursing, Faculty of Nursing Universitas Padjadjaran; laili.rahayuwati@unpad.ac.id \\ 3Department of Community Nursing, Faculty of Nursing Universitas Padjadjaran; mamat_lukman@yahoo.com \\ ${ }^{4}$ Department of Medical Surgical Nursing, Faculty of Nursing Universitas Padjadjaran; \\ kusman_ibrahim@yahoo.com \\ 5Department of Pediatric Nursing, Faculty of Nursing Universitas Padjadjaran; ikeu.nurhidayah@gmail.com \\ Correspodence: laili.rahayuwati@unpad.ac.id
}

Type of the Paper (Article)

Received: May 8, 2019; Accepted: June 11, 2019; Published: August 13, 2019 https://doi.org/10.29253/achnr.2019.12618

\begin{abstract}
Cervical cancer is a disease that mostly affects women. The incidence of cervical cancer is quite high. Therefore, it is necessary to carry out cervical cancer prevention, especially primary prevention. However, cervical cancer prevention behavior is still relatively low. One of the factors that influence is the perception of cervical cancer prevention. This study aimed to identify perceptions of primary cervical cancer prevention in female high school students. This study used descriptive quantitative methods. The sampling technique used stratified random sampling. The study was conducted on female students of SMAN Tanjungsari with a sample of 216 people. Data collection was obtained using a questionnaire with a Likert scale, consisting of perceptions of susceptibility, severity, benefits, and barriers. The instrument was affirmed valid with a range of $0.367-0.717$ and the reliability value of the questionnaire was 0.811 . The analysis was statistic descriptive. The results showed that most female students of SMAN Tanjungsari had negative perceptions of cervical cancer susceptibility (94.9\%), positive perceptions of cervical cancer severity (94\%), positive perceptions of primary cervical cancer prevention benefits (98.6\%), and positive perceptions of primary cervical cancer prevention barriers (96.8\%). This study concludes that most of the female students of SMA Tanjungsari have a positive perception of primary cervical cancer prevention. Based on these results, health services and educational institutions should be able to develop cervical cancer prevention programs which are accessible to all students so that it will be a supporting factor for high school female students in their efforts to prevent cervical cancer.
\end{abstract}

Keywords: cervical cancer; female students; perception

\section{Introduction}

Cervical cancer is a disease caused by malignant tumors in the cervical region as a result of uncontrolled tissue growth and damage to healthy tissue around it (American Cancer Society, 2012). Women of reproductive age have a risk of cervical cancer. The ages at risk for cervical cancer are 15 - 44 years (Globocan, 2012). The leading cause of cervical cancer is a Human Papilloma Virus (HPV) infection. 
HPV is a virus that infects the skin and human mucous membranes that can be transmitted through sexual intercourse (Setiawati, 2014).

Cervical cancer is the third most common type of cancer in women in the world after breast cancer and colorectal cancer. The number of cases in 2012 was around 528,000 new cases and 266,000 deaths. The prevalence occurs mostly in developing countries. Cervical cancer cases that occur in the South East Asia Region (SEARO) in Indonesia are 175,000 new cases in 2012, with a total death toll of 94,000. Cervical cancer ranks second-most in cancer cases in women in Asia (Globocan, 2012).

In Indonesia, cervical cancer ranks first in cancer cases in women. In year 2010, the prevalence of cervical cancer in Indonesia is 96,692 cases. Indonesia even has the highest number of cervical cancer cases in the world. In West Java, there are 15,635 cases of cervical cancer or around $0.7 \%$ (Riskesdas, 2013).

The increasing number of incidents shows that every woman should prevent cervical cancer from avoiding an increase in cervical cancer cases. In Indonesia, only 5\% perform prevention and early detection of cervical cancer (Setiawati, 2014). In 2015, Indonesia's Minister of Health made a Cancer Mitigation Commitment in Indonesia, intending to make cancer one of the priorities of national health issues and seek promotive and preventive programs. Particular attention is to increase promotion and preventive efforts to raise public awareness of cancer as well as the development of early detection efforts to reduce cancer deaths (Indonesian Ministry of Health Data and Information Center, 2015).

Cervical cancer prevention is divided into primary, secondary and tertiary prevention. Primary prevention for cervical cancer is promotion and education of a healthy lifestyle, delaying the onset of sexual activity, use of barrier contraception and use of HPV vaccination. Secondary prevention is by screening a Pap smear or VIA (Visual Inspection with Acetic acid) test. Secondary prevention can only be done on women who have had sexual relations. Tertiary prevention is in the form of palliative and rehabilitative care and is given to people who have cervical cancer (Rasjidi, 2009).

According to the Indonesian Ministry of Health (2016), the age of women of childbearing age is 1549 years. Research by Hidayat et al. (2014) showed that the period at high risk of cervical cancer is more than 50 years. A study by Lasut et al. (2015) showed that the age of cervical cancer patients is 35-59 years. The development of cervical cancer cells does not occur in a fast time; even the development time is between 5 to 20 years. This shows that people diagnosed with cervical cancer at the age of more than 30 years have the possibility of being infected with cervical cancer from adolescence. Based on these data, the prevention of cervical cancer also needs to be done for a younger age. At present, the Ministry of Health of the Republic of Indonesia (2015) has only created a secondary prevention program for cervical cancer, namely the IVA (Inspeksi Visual Asam Asetat- Visual Inspection with Acetic acid - VIA) test. Generally, secondary prevention is carried out on women of childbearing age who are married. Whereas for primary prevention has not been programmed by the government. Viewing the data on women of childbearing age who are affected by cervical cancer are increasingly younger, the adolescents also need prevention.

The cervical cancer prevention behavior in young women or adolescents is still relatively low. A study conducted by Sylvana (2012) reveals that the cervical cancer prevention behavior in female students at the Psychology Faculty, University of Indonesia is still negative. In that study, the cervical cancer prevention behavior in female students assessed is exercise, healthy nutrition, not smoking and not having sex. Subsequently, a study conducted by Utami et al. (2013) indicates the cervical cancer prevention behavior in the form of early detection in women of childbearing age is relatively low at $68 \%$. Another study by Farfar (2011) shows the average cervical cancer prevention behavior at SMAN Kei is 6.95. Preventive behaviors assessed are a healthy lifestyle, early sexual relations, smoking, exercise, and vaginal discharge. Several previous studies indicate, there is a tendency that perceptions will influence cervical cancer behavior and its prevention. A study conducted by Hopman (2015), reveals that the perceived severity of the disease can affect a person's mindset and behavior regarding a particular disease. An individual's perception of cervical cancer prevention will affect a person's behavior towards cervical cancer, especially in efforts to prevent cervical cancer.

Indonesia consists of 34 provinces and West Java is the province with the largest population in Indonesia (Indonesian Ministry of Health, 2017). Sumedang Regency is one of the regencies in West Java. According to data from Sumedang District Hospital, from 2015 to 2017, 50 people were diagnosed with cervical cancer, with an age range of 26 years to over 65 years. Sumedang Regency has 19 sub-districts, 
each of which has a cervical cancer incidence. One of the sub-districts in Sumedang Regency with the highest rate of cervical cancer is Tanjungsari District with four occurrences.

Tanjungsari Subdistrict has an early marriage phenomenon of girls under the age of 18. According to data from the KUA of Tanjungsari District in 2017, 81 girls married at a young age, below the age of 18, with the youngest age being 12 years. According to Globocaan (2012) women have a risk of cervical cancer from the age of 15 years. This age includes high school age and can be one of the risk factors for cervical cancer.

Based on a preliminary study conducted at SMAN Tanjungsari, it found that every year there were female students who quit school to get married due to pregnancy outside marriage or family economic factors. The study of Has and Hendrati (2009) reveals that early sexual intercourse (age less than 20 years), changing sexual partners and genital hygiene are factors that can trigger cervical cancer. Then, based on the results of interviews with some female students of SMAN Tanjungsari, it found that 4 out of 20 people knew about HPV vaccination, but 19 of 20 people knew about vaccines. The purpose of this study is to describe how adolescence perceive toward cervical cancer.

\section{Methods}

This descriptive quantitative study had a perception variable on primary cervical cancer prevention. The variable component of this study was based on the Health Belief Model theory, namely the perception of disease susceptibility, disease severity, the benefits of prevention and the barriers prevention.

The population of this study was students of SMAN Tanjungsari. The criterium of the population was female. The total population was 468 people who were selected from females' students in classes $X$ and XI. The number of samples in this study was determined using the Slovin formula with a set error rate or precision of $5 \%$. The sampling technique used stratified random sampling, which is used if the population consists of several levels. The number of samples obtained had an error rate of 5\%, namely 216 female students.

Stratified sampling was used with any reasons: the sample is student of different grades, every class us represented as sample in this study. Determination of sample units is done randomly by drawing on every grade $(10,11)$. The drawing is done using the Microsoft Excel comuter program.

The questionnaire was developed based on the Health Belief Model concept on preventive health behavior. The researcher modified the questionnaire used in the study by Wigati (2016). The source for building instruments is theory of Health Belief Model and some literature review. The instrument had modified to make appropriate with adolescents as respondents, because the previous respondents was women.

The data analysis used in the domain of perception of primary cervical cancer prevention was descriptive statistics by summing all the scores of statement items and then looking for the cut off point. According to Tam (2001), the cut off point is a method used to ascertain the degree of need for the criteria. All statement items are summed from the highest value to the lowest value then the cut off point is searched. The research ethics was carried out through the Research Ethics Commission of Universitas Padjadjaran, with number 417/UN6.KEP/EC/2018.

\section{Results}

The characteristics of the respondents in this study included age and class. Respondent characteristics data provided information about the variation of respondents in this study.

Table 1. Frequency Distribution of Characteristics of SMAN Tanjungsari Female Students $(\mathrm{n}=216)$

\begin{tabular}{|c|c|c|c|}
\hline No. & Respondent & Frequency (f) & Percentage (\%) \\
\hline \multirow[t]{5}{*}{1} & Age & & \\
\hline & 15 Years & 35 & 16.2 \\
\hline & 16 Years & 111 & 51.4 \\
\hline & 17 Years & 68 & 31.5 \\
\hline & 18 Years & 2 & 0.9 \\
\hline \multirow[t]{3}{*}{2.} & Class & & \\
\hline & $\mathrm{X}$ & 113 & 52.3 \\
\hline & XI & 103 & 47.7 \\
\hline
\end{tabular}


Based on the frequency distribution of characteristics, it found that 111 respondents (51.4\%) were 16 years old. Most students (52.3\%) are from grade 10, and most of them (82.9\%) are between 16 and 17 years age (Table 1 ).

Table 2 Frequency Distribution of Perceptions of SMAN Tanjungsari Female Students towards Primary Cervical Cancer Prevention $(n=216)$

\begin{tabular}{|c|c|c|c|c|}
\hline \multirow{2}{*}{ Perception } & \multicolumn{2}{|c|}{ Positive } & \multicolumn{2}{|c|}{ Negative } \\
\hline & Frequency (f) & Percentage (\%) & Frequency (f) & Percentage (\%) \\
\hline $\begin{array}{l}\text { Perceived } \\
\text { Susceptibility }\end{array}$ & 11 & 5.1 & 205 & 94.9 \\
\hline $\begin{array}{l}\text { Perceived } \\
\text { Severity }\end{array}$ & 203 & 94 & 13 & 6 \\
\hline $\begin{array}{l}\text { Perceived } \\
\text { Benefits }\end{array}$ & 213 & 98.6 & 209 & 96.3 \\
\hline $\begin{array}{l}\text { Perceived } \\
\text { Barriers }\end{array}$ & 209 & 96.3 & 8 & 3.7 \\
\hline $\begin{array}{l}\text { Total } \\
\text { of perception }\end{array}$ & 196 & 90.7 & 20 & 9.3 \\
\hline
\end{tabular}

Source: Primary data

Based on the frequency distribution of perceptions of SMAN Tanjungsari female students towards Primary Cervical Cancer Prevention, the result showed, mostly had a positive perception (90.7\%). Based on the frequency distribution of perceptions of SMAN Tanjungsari female students on cervical cancer based on susceptibility, severity, benefits, and barriers, it found that the perception of female high school students was mostly negative (94.9\%). Whereas the barriers in primary cervical cancer prevention mainly were positive (96.8\%) (Table 2$)$.

Table 3 Frequency Distribution of Perceptions of SMAN Tanjungsari Female Students towards Susceptibility, Severity, Benefits, and Barriers Based on Characteristics of Respondents ( $\mathrm{n}=216)$

\begin{tabular}{|c|c|c|c|c|c|c|c|c|c|c|c|c|c|c|c|c|}
\hline \multirow{5}{*}{ Characteristics } & \multicolumn{16}{|c|}{ Cervical Cancer Perception } \\
\hline & \multirow{2}{*}{\multicolumn{4}{|c|}{$\begin{array}{c}\text { Susceptibility } \\
\text { Perception }\end{array}$}} & \multirow{2}{*}{\multicolumn{4}{|c|}{ Severity Perception }} & \multirow{2}{*}{\multicolumn{4}{|c|}{ Benefits Perception }} & \multirow{2}{*}{\multicolumn{4}{|c|}{ Barriers Perception }} \\
\hline & & & & & & & & & & & & & & & & \\
\hline & \multicolumn{2}{|c|}{ Positive } & \multicolumn{2}{|c|}{ Negative } & \multicolumn{2}{|c|}{ Positive } & \multicolumn{2}{|c|}{ Negative } & \multicolumn{2}{|c|}{ Positive } & \multicolumn{2}{|c|}{ Negative } & \multicolumn{2}{|c|}{ Positive } & \multicolumn{2}{|c|}{ Negative } \\
\hline & $\mathrm{f}$ & $\%$ & $\mathrm{f}$ & $\%$ & $\mathrm{f}$ & $\%$ & $\mathrm{f}$ & $\%$ & $\mathrm{f}$ & $\%$ & $\mathrm{f}$ & $\%$ & $\mathrm{f}$ & $\%$ & $\mathrm{f}$ & $\%$ \\
\hline \multicolumn{17}{|l|}{ Age } \\
\hline 15 years & 0 & 0 & 35 & 100 & 33 & 94.3 & 2 & 5.7 & 35 & 100 & 0 & 0 & 35 & 100 & 0 & 0 \\
\hline 16 years & 9 & 8.1 & 102 & 91.9 & 105 & 94.6 & 6 & 5.4 & 110 & 99.1 & 1 & 0.9 & 107 & 94.6 & 4 & 3.6 \\
\hline 17 years & 1 & 0.5 & 67 & 98.5 & 63 & 92.6 & 5 & 7.4 & 66 & 97.1 & 2 & 2.9 & 64 & 94.1 & 4 & 5.9 \\
\hline 18 years & 0 & 0 & 2 & 100 & 2 & 100 & 0 & 0 & 2 & 100 & 0 & 0 & 2 & 100 & 0 & 0 \\
\hline \multicolumn{17}{|l|}{ Class } \\
\hline Class X & 10 & 8.9 & 103 & 91.1 & 107 & 94.7 & 7 & 6.3 & 113 & 100 & 0 & 0 & 109 & 96.5 & 4 & 3.5 \\
\hline Class XI & 1 & 0.9 & 102 & 99.1 & 97 & 94.2 & 6 & 5.8 & 100 & 97.1 & 3 & 2.9 & 99 & 96.1 & 4 & 3.9 \\
\hline
\end{tabular}

Source: Primary Data

From the frequency distribution of perceptions of SMAN Tanjungsari female students to susceptibility, severity, benefits, and barriers based on the respondent's characteristics, it found that $100 \%$ of respondents aged 15 years and 18 years had a negative perception of cervical cancer susceptibility. A total of $94.6 \%$ of respondents aged 16 years had a positive perception of cervical cancer severity. A total of $99.1 \%$ of respondents aged 16 years had a positive perception of the benefits of primary cervical cancer prevention. While $96.4 \%$ of respondents aged 16 years had negative perceptions of the barriers to primary cervical cancer prevention (Table 3). Respondents perceived 
primary cervical cancer prevention well and had a high chance of being able to perform cervical cancer prevention behaviors.

\section{Discussion}

Based on data analysis on susceptibility perceptions of cervical cancer, it found that most students had negative perceptions. This showed that SMAN Tanjungsari female students did not feel susceptible to cervical cancer. In their study, Wigati, Budihastui, Murti (2016) have expressed a similar view that the susceptibility perception in women of childbearing age toward cervical cancer prevention or early detection of cervical cancer was low. Moreover, individuals who considered themselves susceptible to cervical cancer or positive to cervical cancer susceptibility perceptions will have a higher chance of carrying out preventive behavior for cervical cancer, both primary and secondary prevention.

Rosenstock (1994) states that the assumption that a person is susceptible to illness will make the individual do something for protection. A study conducted by Has, Hendrari (2007) states that women who have a perception of high or positive cervical cancer susceptibility will prevent cervical cancer. In the study, the preventive behavior carried out is HPV vaccination.

Things considered in the susceptibility perception are risk factors possessed by individuals which can cause cervical cancer. Factors that become the risk of cervical cancer are genetic or hereditary factors, changing sexual partners, often suffering from genital infections or exposure to sexually transmitted diseases (Ministry of Health, 2015). The risk factors contained in the questionnaire of respondents' perceptions of cervical cancer, were in part of perceptions of cervical cancer susceptibility. From the results obtained, respondents felt that they did not have these risk factors and thus had a negative perception of cervical cancer susceptibility. There were two possibilities, which could cause respondents to have a negative perception of susceptibility, that is, feeling that they did not have risk factors for cervical cancer or did not have the awareness that they had a risk of cervical cancer. Therefore, it required an effort to increase the risk factor awareness for cervical cancer which could be carried out by providing health education on cervical cancer to female high school students.

Based on data analysis on perceptions of cervical cancer severity, the results showed that most students had positive perceptions. This showed that respondents considered cervical cancer as a severe disease and had an impact on oneself and the family. This is in line with research by Nugrahaini, Budihastuti, Pamungkasari (2017), which states that women of childbearing age have a positive perception of the seriousness or severity of cervical cancer.

The severity perception comes from a person's belief in the disease, which is related to gravity and the impact it causes will lead to death, disability or pain. Besides, the impact will affect psychological, social (work, family life) and economic functions (Champion \& Skinner, 2008).

A study by Oktaviana (2015) states that women of childbearing age with a high severity perception of the disease, have a 15.49 times greater chance of prevention and early detection of cervical cancer than women of childbearing age with low disease severity perception. This shows that women who feel that cervical cancer is a severe disease will have the opportunity to make prevention efforts, both primary and secondary prevention.

Based on data analysis on perceptions of the benefits of cervical cancer primary prevention, the results revealed that most students had a positive perception. A study by Nugrahaini, Budhihastuti, Pamungkasari (2017) suggests that women of childbearing age have a positive perception of the benefits of preventing cervical cancer, in this case, the cervical cancer prevention is the Human Papilloma Virus vaccine.

There are several barriers to one's belief that certain actions can reduce the threat of disease. These barriers are obstructions to the steps that will be taken to reduce or avoid the threat of disease. These barriers become obstacles in carrying out health actions. If these obstacles are not felt then steps for reducing the disease threat will have the opportunity to be carried out (Rosenstock, 1994). In this study the perceived barriers to cervical cancer primary prevention were positive, meaning that the respondents had no obstacles in doing cervical cancer primary prevention, so there is an excellent opportunity for carrying out primary prevention behavior. 


\section{Conclusions}

The Female student perceptions of cervical cancer primary prevention are mostly positive. However, the results of the study show that almost all respondents have a negative susceptibility perception of cervical cancer.

Almost all respondents have a positive perception of cervical cancer severity, perception of benefits, and perception of barriers primary cervical cancer prevention. This shows that Tanjungsari female students feel that cervical cancer is a disease that has a severe impact both on people who suffer from the disease and the families of sufferers, primary cervical cancer prevention can provide benefits in preventing cervical cancer, and they have no barriers in performing primary cervical cancer prevention.

For health care providers, it is recommended to maximize prevention and promotion programs regarding cervical cancer prevention. This can be carried out by conducting health education for high school students to maintain an excellent cervical cancer perception.

Conflicts of Interest: No conflict of interest

\section{References}

American Cancer Society. (2012). Cervical Cancer Causes, Risk Factors, and Prevention. Retrieved from https://www.cancer.org/content/dam/CRC/PDF/Public/8600.00.pdf

Champion, V. L., \& Skinner, C. S. (2008). The Health Belief Model (4th ed.). USA: John Wiley \& Sons

Farfar, W.J. (2011). Hubungan Pengetahuan Remaja Tentang Kanker Serviks dan Perilaku Pencegahan Kanker Serviks Di SMA Negeri 1 Kei Kecil. SKRIPSI http://digilib.esaunggul.ac.id/5070/UEU-Undergraduate-5070bab6-hubungan-pengetahuan-remaja-tentang-kanker-serviksdan-perilaku-pencegahan-kanker-serviksdisma-negeri-1-kei-kecil.pdf

Globocan. (2012). Cervical Cancer Estimated Incidence, Mortality and Prevalence Worldwide in 2012. Diakses pada 25 Oktober 2017. Retrieved from: http://globocan.iarc.fr/old/FactSheets/cancers/cervix-new.asp

Has, D F S., \& Hendrari, L Y. (2007). Faktor risiko karakteristik dan perilaku seksual terhadap kejadian kanker serviks. The Indonesian Journal of Public Health, 6(1), 38-43. Retrieved from https://media.neliti.com/media/publications/3882-ID-faktor-risiko-karakteristik-dan-perilaku-seksualterhadap-kejadian-kanker-servik.pdf

Hidayat, E., Hasibuan, D H S., \& Fitriyati, Y. 2014. Hubungan kejadian kanker serviks dengan jumlah paritas di RSUD $\begin{array}{lllll}\text { DR.Moewardi. } & \text { JKKI, } & \text { 6(3), } & \text { Retrieved }\end{array}$ http://journal.uii.ac.id/index.php/JKKI/article/view/3389

Hopman, Petra., \& Rijken, Mieke. (2015). Illness Perceptions of Cancer Patients: Relationships with Illness Characteristics and Coping. Psycho-Oncology, 24(1), 11-18. Retrieved from: https://www.ncbi.nlm.nih.gov/pubmed/24891136

Institute for Work and Health. (2015). Primary, Secondary and Tertiary Prevention. At Work, Issue 80, Spring 2015. Retrieved from https://www.iwh.on.ca/what-researchers-mean-by/primary-secondary-and-tertiaryprevention

Kementerian Keseatan RI. (2015). Situasi Penyakit Kanker, Data dan Informasi Kesehatan. Jakara: Kementerian Kesehatan RI

Kementerian Kesehatan RI. (2016). Profil Kesehatan Indonesia Tahun 2015. Jakarta: Kementerian Kesehatan RI. Kementerian Kesehatan RI. (2017). Profil Kesehatan Indonesia Tahun 2016. Jakarta: Kementerian Kesehatan RI.

Lasut, E., Rarung, M., \& Suparman, E. (2015). Karakteristik penderita kanker serviks di BLU RSUP Prof.Dr.D.Kandou. $\begin{array}{lllll}\text { Jurnal } & \text {-Clinic } & \text { (eCl), } & \text { 83),86. } & \text { Retrieved }\end{array}$ https://ejournal.unsrat.ac.id/index.php/eclinic/article/view/6519/6268

Tam, M.C.Y., Tummala, V.M.R. (2001). An application of the AHP in vendor selection of a telecommunications system. Omega, The International Journal of Management Science, 29, 171-182. Retrieved from http://citeseerx.ist.psu.edu/viewdoc/download?doi=10.1.1.625.9608\&rep=rep1\&type=pd

Nugrahaini, R.R., Budihastuti, U.R., \& Pamungakasari, E.P. (2017). Health belief model on the factors associated with the use of hpv vaccine for the prevention of cervical cancer among women in Kediri, East Java. Journal of Epidemiology and Public Health, 2(1), 70-81. Retrieved from https://doi.org/10.26911/jepublichealth.2017.02.01.07 
Pusat Data dan Informasi Kementerian Kesehatan RI. (2015). Buletin Jendela Data dan Informasi Kesehatan. Diakses pada 24 Oktober 2017: http://www.depkes.go.id/resources/download/pusdatin/infodatin/infodatinkanker.pdf.

Rasjidi., \& Imam. (2009). Deteksi Dini dan Pencegahan Kanker pada Wanita. Jakarta: CV Sagung Seto

Diterjemahkan oleh: Diana A, Ria C, Abdul R. Jakarta: Salemba Empat.

Rosenstock, I.M., (1994). Historical Origins of the Health Belief Model. Health Education Monographs, 2(4), 328-335. Retrieved from:

http://www.scirp.org/(S(czeh2tfqyw2orz553k1w0r45))/reference/ReferencesPapers.aspx?ReferenceID= 114966

Setiawati, Dewi. (2014). Human Papilloma Virus Dan Kanker Serviks. Public Health Science Journal, 6(2), 450-459. Retrieved from http://journal.uin-alauddin.ac.id/index.php/Al-Sihah/article/download/1969/1898

Sylvana. (2012). Gambaran tingkat pengetahuan dan perilaku pencegahan kanker serviks pada mahasiswi S1 reguler Fakultas Psikologi Universitas Indonesia tahun 2012. Skripsi Universitas Indonesia.

Utami, N.M., Irdawati, Zulaichah,E. (2013). Hubungan tingkat pengetahuan pasangan usia subur dengan Perilaku deteksi dini kanker serviks di wilayah kerja Puskesmas Sangkrah Kecamatan Pasar Kliwon Surakarta.

Wigati, P.W., Budihastui, U.R., \& Murti, B. (2016). Analisis Jalur Dengan Health Belief Model Tentang Penggunaan Skrining Inspeksi Visual Asam Asetat Untuk Deteksi Dini Kanker Serviks Pada Wanita Usia Subur di Kota Kediri. Tesis. Pasca Sarjana Universitas Sebelas Maret Surakarta 